\title{
Review
}

\section{Gene-environment interaction and male reproductive function}

\author{
Jonatan Axelsson ${ }^{1,2}$ Jens Peter Bonde ${ }^{3}$, Yvonne L. Giwercman ${ }^{4}$, Lars Rylander ${ }^{2}$, Aleksander Giwercman ${ }^{1,4}$ \\ ${ }^{1}$ Reproductive Medicine Centre, Skåne University Hospital, Malmö 20502, Sweden \\ ${ }^{2}$ Division of Occupational and Environmental Medicine, Lund University, Lund 22185, Sweden \\ ${ }^{3}$ Department of Occupational Medicine, Copenhagen University, Bispebjerg Hospital, Copenhagen NV 2400, Denmark \\ ${ }^{4}$ Department of Clinical Sciences, Malmö, Lund University, Malmö 20502, Sweden
}

\begin{abstract}
As genetic factors can hardly explain the changes taking place during short time spans, environmental and lifestyle-related factors have been suggested as the causes of time-related deterioration of male reproductive function. However, considering the strong heterogeneity of male fecundity between and within populations, genetic variants might be important determinants of the individual susceptibility to the adverse effects of environment or lifestyle. Although the possible mechanisms of such interplay in relation to the reproductive system are largely unknown, some recent studies have indicated that specific genotypes may confer a larger risk of male reproductive disorders following certain exposures. This paper presents a critical review of animal and human evidence on how genes may modify environmental effects on male reproductive function. Some examples have been found that support this mechanism, but the number of studies is still limited. This type of interaction studies may improve our understanding of normal physiology and help us to identify the risk factors to male reproductive malfunction. We also shortly discuss other aspects of gene-environment interaction specifically associated with the issue of reproduction, namely environmental and lifestyle factors as the cause of sperm DNA damage. It remains to be investigated to what extent such genetic changes, by natural conception or through the use of assisted reproductive techniques, are transmitted to the next generation, thereby causing increased morbidity in the offspring.
\end{abstract}

Asian Journal of Andrology (2010) 12: 298-307. doi: 10.1038/aja.2010.16; published online 29 March 2010.

Keywords: endocrine disruption, gene-environment interaction, persistent organic pollutants, semen quality, testicular cancer

\section{Introduction}

A time-related deterioration of male reproductive health during the past few decades has been suggested $[1,2]$, although these epidemiological trends remain debated $[3,4]$. The most obvious example is the

Correspondence to: Prof. Aleksander Giwercman, Reproductive Medicine Centre, Skåne University Hospital, Malmö 205 02, Sweden. Fax: +46-40-338-266

E-mail: Aleksander.Giwercman@med.lu.se

Received: 16 February 2010 Accepted: 22 February 2010

Published online: 29 March 2010 marked increase in the incidence of testicular cancer (TC) [5]. Concomitantly, it has been claimed that also malformations in the male reproductive tract, such as hypospadias [6] and cryptorchidism [7], have become more common. Furthermore, some reports have indicated a decline in sperm counts $[8,9]$.

Significant ethnic differences in the epidemiological trends in relation to male reproductive function have been observed. Thus, white Americans have a substantially higher incidence of TC than AfricanAmericans [10]. The observation of a decline in sperm counts has been limited to some Western countries, but data for other parts of the world are very limited [9]. 
The rapidity of the deterioration in male reproductive health, which is most evident in the TC risk, points to an influence of environmental or lifestyle-related factors. Considering the major ethnic differences in the occurrence of TC, it seems likely that genetic predisposition may modify adverse environmental effects. Insight into gene-environment (lifestyle) interaction in relation to the disorders of the male reproductive function may help establish causal inference. Observational studies are prone to confounding and bias $[11,12]$. If associations between environmental factors and outcomes are modified by genetic factors in the predicted direction, this may greatly add to the reliability of the conclusions (see, for instance, a review of the studies on alcohol and oesophageal cancer modified by alcohol dehydrogenase enzymes [13]).

In general terms, gene-environment interaction relates to the presence or absence of certain genetic variants influencing the risk of developing a disease due to environmental exposure or lifestyle (Figure 1) [14]. The concept has been linked to many other major pathologies as, for example, cancer [15, 16], obesity [17], diabetes and cardio-vascular diseases [18, 19], but regarding the disorders of the reproductive system, these mechanisms are not yet fully clarified and may also have other implications.

Another aspect of gene-environment interaction with specific relevance for the reproductive system is the possibility that environmental or lifestyle-related factors may affect the genome of the gamete, with a danger of phenotypic changes in the generations to come.

The aim of this paper is to critically review the current knowledge regarding gene-environment interaction and male reproductive function, based on relevant data in PubMed as well as based on our own research. In this context, we will also shortly discuss the alterations in the sperm genome related to environmental exposure or life style.

\section{Testicular dysgenesis syndrome}

The concept of testicular dysgenesis syndrome (TDS) was introduced in 2001 [20], suggesting that poor semen quality, testicular germ cell cancer, undescended testis and hypospadias were manifestations of one underlying entity (Figure 2). TDS was thought to be a result of disrupted embryonal programming and
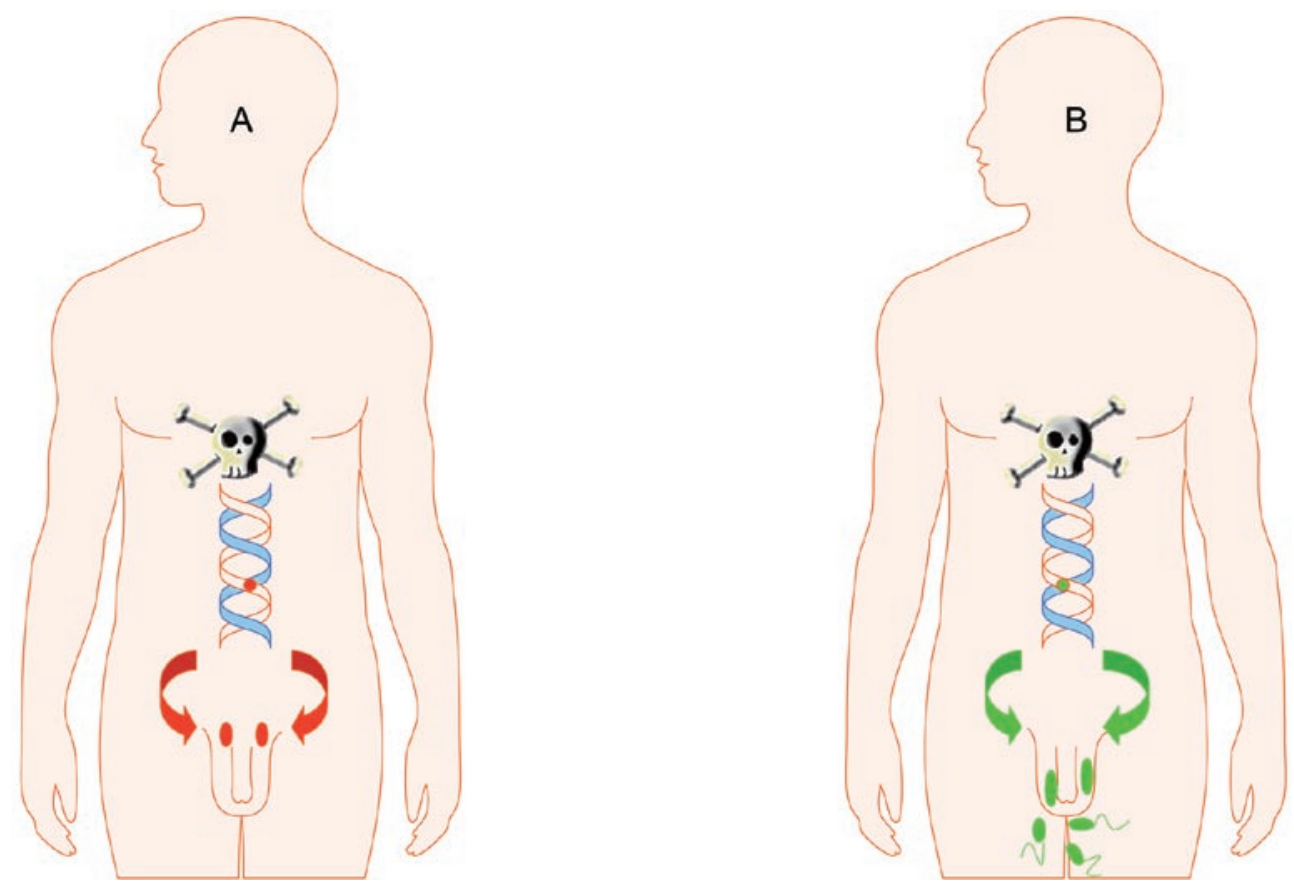

Figure 1. Schematic view of the concept of gene-environment interaction in relation to male reproductive function. Two subjects exposed to the same environmental toxicant: (A): Man with a genetic variant implying increased susceptibility-cryptorchidism, testicular atrophia and no sperm production. (B): Man with a genetic variant encoding for less susceptibility. 
gonadal development during foetal life. Man-made chemicals that interfere with the function of endocrine systems, so-called endocrine disrupters (EDs), have been suggested as risk factors for TDS and are supposed to act on a susceptible genetic background.

\section{Gene-environment interaction and animal studies}

A number of animal studies have shown that genetic background may influence the susceptibility to effects of ED on the male reproductive system. The effects of a potent toxicant, 2,3,7,8-tetrachlorodibenzo- $p$-dioxin (TCDD), that is supposed to act through the aryl hydrocarbon receptor (AHR) have been studied in rats. Following exposure to TCDD in adult life, strains with a mutated AHR allele had a less pronounced decrease in spermatogenesis than those with the wild-type receptor [21]. Similarly, when exposed to the same compound in utero, males of the rat strains carrying the mutated allele had a lower decrease in daily sperm production and epididymal sperm reserves than counterparts with the wild-type allele when measured on postnatal day 70 [22]. Thus, the effects of TCDD exposure on spermatogenesis seemed to be decreased in rats with a mutated AHR, implying that a fully functioning receptor is needed for maximal negative exposure effects on spermatogenesis. Although it is not fully explained how a mutated AHR can protect against the deleterious effects of dioxin on sperm number, the paper by Simanainen et al. [22] showed that the effect is not mediated through reduction in testosterone production or poor development of seminal vesicles.

Further, the testicular toxic effects of exposure in utero to the plasticizer dibutyl phthalate were reported to differ between two different substrains of Long-Evans rats [23]. Out of the two strains, one had an inherited increased risk for cryptorchidism and also, following the phtha- late exposure in utero, a significantly higher risk of reduction in prepubertal testis weight, signs of Leydig cell disturbance and increased histological defects in seminiferous cords.

However, in general, exposure levels far above those found in humans have been needed to evoke reproductive toxicity in the animal models and most studies have mainly been based on exposure to single compounds, not mimicking the multi-agent exposure of humans. These reports have therefore often been overlooked and regarded as not relevant to humans.

\section{Human male reproductive function and gene- environment interaction}

\subsection{Testicular cancer}

There are several epidemiological trends indicating that environmental or lifestyle factors are important players in relation to the increase in incidence of $\mathrm{TC}$ seen during the past $4-5$ decades [2]. The rapidity by which the increase in TC incidence has taken place, in combination with the fact that TC incidence seems to follow birth cohorts, indicates a strong environmental contribution to the underlying aetiology. Thus, countries like Sweden, Norway and Denmark all report a decreased risk of this malignancy among men born during the Second World War [2]. The reasons are still unknown, but could be related to alterations in the way of living during the war. It is also puzzling that significant differences in TC incidence can be found when comparing the Nordic countries that are geographically, socially and culturally very closely related: TC is twice as common in Sweden and five times more common in Denmark and Norway as in Finland [5]. In this case, a purely genetic explanation is appealing. However, epidemiological data indicate that the environment in the country where one is born

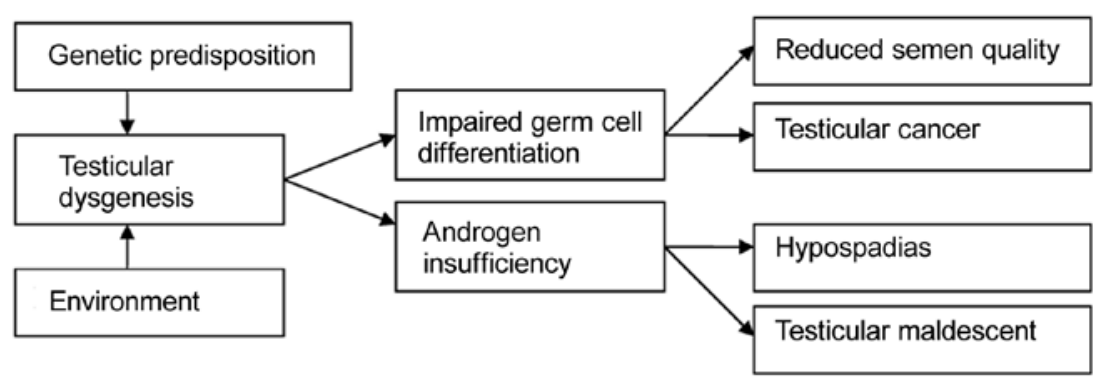

Figure 2. Simplified schematic presentation of pathogenic links in testicular dysgenesis syndrome (adapted from ref [17]). 
or grows up plays an important role. Thus, in a recent study from Denmark, the relative risk of TC in all firstgeneration immigrants was much lower than the risk among sons of Danish parents born in Denmark [24]. However, in the second-generation immigrants, the relative risk increased to an incidence almost as high as that in the general population of Danes. This was in line with an earlier Swedish study that showed that TC incidence among first-generation Finnish immigrants in Sweden was only around $40 \%$ of the Swedish incidence, whereas the second generation had an incidence that was more similar to that in Swedish men [25]. These observations and the fact noted in the Danish study, that first-generation immigrant men arriving in Denmark, as early as before the age of 10 , did not seem to have any increased risk compared with men arriving later, strongly indicate a substantial influence of environmental factors, probably in utero, in early childhood or at pubertal age [24]. Somewhat blurring the pattern was the finding in the Swedish study that second-generation sons of two Danish parents living in Sweden still had a doubled risk compared with the Swedish men, almost similar to the risk of the first-generation Danish men, indicating a particular link between TC risk and Danish habits [25], as sons of one Danish parent had an incidence similar to that of Swedish men. The same was true for secondgeneration immigrants born in Sweden and having one Finnish parent, with those men having a TC incidence that is approximately the same as the incidence in Swedish men.

Mothers of men with TC have been reported to have higher concentrations of certain persistent organic pollutants (POPs), such as polychlorinated biphenyls (PCBs), as compared with women without sons having this disease $[26,27]$.

There are several indications of the role of genetic susceptibility in relation to the risk of TC. Brothers of affected men are at almost nine times increased risk of developing $\mathrm{TC}$, this risk being higher than that for most other cancer types [28]. In twin brothers the risk of TC is nearly 40 times increased, being almost two times higher in dizygotic (DZ) twins as compared with monozygotic (MZ) twins. This discrepancy was suggested to be due to the higher sex steroid and gonadotropin levels in DZ than in MZ pregnancies [29].

Recent molecular studies have identified some genetic variants associated with the risk of TC. It is well known that subjects with androgen insensitivity syndrome due to mutation in the androgen receptor gene have a very high risk of TC [30].

A recent genome-wide association study found strong evidence for a link between certain singlenucleotide polymorphisms (SNPs) on chromosomes 5, 6, 12 and the risk of TC. The odds ratios (OR) per allele were found to be $1.4,1.5$ and 2.6, respectively [31]. The SNPs were all shown to have a dose-response effect in a log-additive model, that is, men homozygous for the high-risk alleles on chromosome 12 had a six times increased relative risk.

In another study investigating the impact of genes encoding for enzymes metabolizing certain EDs as well as hormones, polymorphisms in two genes, CYP1A1 (cytochrome P450, family 1, subfamily A, polypeptide 1) and hydroxysteroid (17-beta) dehydrogenase 4 (HSD17B4), were found to modify the associations between levels of exposure to different POPs and the risk of TC [32]. Men highly exposed to the pesticide chlordane and one of its metabolites, previously reported to be associated with the risk of TC [33], had a higher TC risk only if they carried two certain less common polymorphisms in the CYP1A1 gene. Two other SNPs in the gene had previously been reported to appear to protect against the disease [34], and although the functional aspects of these genetic variations in relation to enzymatic activity are not fully clarified, it is plausible to assume that the human levels of ED are dependent not only on the level of exposure, but also on the rate of metabolism.

Men with a high exposure to some PCBs had already been reported to have a lower incidence of TC [35], but, according to the previously mentioned study, seemed to be protected by the PCBs only if they had a homozygous allele of the HSD17B4 gene [32] (Table 1). These findings point to gene-environment interactions in relation to the association between ED exposure and TC risk. However, as many interactions across a number of POPs and SNPs were examined, the probability of false interactions was not negligible and caution was imposed. Another reason to caution is the relatively short time between the blood sampling for POP analysis and diagnosis (median 4.4 years), as the risk of TC has been suggested to be related to events taking place already during the foetal period and not in adult life, when these blood samples were obtained [36]. However, the biological half-life of POPs is rather long (several years) [37] and high POP levels in adulthood could possibly reflect high levels already in the prenatal period. Higher adult POP levels may not only reflect more extensive exposure but even a lower level of POP 
Table 1. Human studies indicating gene-environment interaction in relation to male reproductive health.

\begin{tabular}{|c|c|c|c|c|}
\hline Population & Genetics & Exposure & Effect & Reference \\
\hline Chinese workers & $\begin{array}{l}\text { Paraoxonase gene PON1 } \\
\text { (organophosphate } \\
\text { metabolism) }\end{array}$ & $\begin{array}{l}\text { Organophosphate } \\
\text { pesticides }\end{array}$ & $\begin{array}{l}\text { Lower sperm count and morphology, } \\
\text { as compared with controls, in exposed } \\
\text { subjects with a gene variant encoding } \\
\text { for a more efficient enzyme }\end{array}$ & {$[51]$} \\
\hline Czech men & $\begin{array}{l}\text { Gluthatione- } S \text {-transferase } \\
\text { M1 (GSTM1) (PAH meta- } \\
\text { bolism) }\end{array}$ & Air pollution & $\begin{array}{l}\text { Higher level of impairment of sperm } \\
\text { chromatin integrity in exposed subjects } \\
\text { with GSTM1 null variant }\end{array}$ & {$[54]$} \\
\hline $\begin{array}{l}\text { Fertile and sub- } \\
\text { fertile Dutch men }\end{array}$ & $\begin{array}{l}\text { Methylenetetrahydrofolate } \\
\text { reductase } M T H F R \text { C677T } \\
\text { polymorphism }\end{array}$ & $\begin{array}{l}\text { Folate and zinc } \\
\text { sulphate supple- } \\
\text { mentation }\end{array}$ & $\begin{array}{l}\text { Increase in sperm concentration only in } \\
\text { those with the wild type of the MTHFR }\end{array}$ & {$[55]$} \\
\hline $\begin{array}{l}\text { European but not } \\
\text { Inuit men }\end{array}$ & $\begin{array}{l}\text { Androgen receptor }(A R) \\
\text { CAG repeat }\end{array}$ & $p, p^{\prime}-\mathrm{DDE}$ & $\begin{array}{l}\text { Higher level of impairment of sperm } \\
\text { chromatin integrity in highly exposed } \\
\text { subjects with CAG repeats of } \leq 21 \text {, } \\
\text { but not in those with a repeat length } \\
\text { of } 22 \text { or more }\end{array}$ & {$[50]$} \\
\hline $\begin{array}{l}\text { European and } \\
\text { Inuit men }\end{array}$ & $A R$ CAG repeat & $\begin{array}{l}\text { Biomarker for PCB } \\
(\mathrm{CB}-153)\end{array}$ & $\begin{array}{l}\text { Forty per cent lower sperm number in } \\
\text { highly exposed men with CAG repeats } \\
<20 \text {, but not in those with longer repeats }\end{array}$ & {$[50]$} \\
\hline $\begin{array}{l}\text { American testicular } \\
\text { cancer patients and } \\
\text { controls }\end{array}$ & $\begin{array}{l}\text { CYP1A1 and HSD17B4 } \\
\text { encoding for hormone- } \\
\text { metabolizing enzymes }\end{array}$ & $\begin{array}{l}\text { Persistent organic } \\
\text { pollutants (POPs) }\end{array}$ & $\begin{array}{l}\text { The association between exposure and } \\
\text { cancer risk modified by the } C Y P 1 A 1 \\
\text { and } H S D 17 B 4 \text { genotypes }\end{array}$ & {$[32]$} \\
\hline
\end{tabular}

Abbreviations: AHR, aryl hydrocarbon receptor; AR, androgen receptor; CAG, a trinucleotide repeat of the nucleotides $\mathrm{C}$, A and $\mathrm{G}$ in the androgen receptor; CYP1A1, cytochrome P450, family 1, subfamily A, polypeptide 1; GSTM1, Gluthatione-S-transferase M1; HSD17B4, hydroxysteroid (17-beta) dehydrogenase 4; MTHFR, methylenetetrahydrofolate reductase; PAH, polyaromatic hydrocarbons; PCB, polychlorinated biphenyls; POP, persistent organic pollutants; $p, p^{\prime}-\mathrm{DDE}$, dichlorodiphenyl dichloroethene; TCDD, 2,3,7,8-tetrachlorodibenzo- $p$-dioxin.

metabolism, implicating that those subjects did have a life-long high exposure to the actual EDs.

\subsection{Fertility and semen quality}

Infertility is a very common condition in Western countries , affecting approximately $15 \%$ of all couples [38]. Despite the fact that the male contribution has been estimated to be $50 \%$ of all cases, very little is known about the causes of impaired semen quality. Some well-known genetic disorders such as Kallmann's syndrome, Klinefelter's syndrome, Y chromosome microdeletions, androgen insensitivity and cystic fibrosis gene mutations only account for a few per cent of cases [39]. Even if cryptorchidism and cancer treatment is added to this list, the majority of cases remain unexplained. Added to this, in this context the impact of environmental and lifestyle-related factors has attracted increasing attention.

Trying to disentangle the impact of genes and environment on semen quality and sex hormone levels, MZ and DZ twin pairs, as well as pairs of singleton brothers, were investigated in a Danish study [40]. Differences in traits among MZ twins were argued to indicate environmental effects, whereas similarity among MZ twins with differences in DZ twins indicated a genetic effect. By comparing twins with singletons, an impact of prenatal environment was estimated. A substantial hereditary component was found in plasma levels of hormones reflecting Sertoli cell function, in sperm cell chromatin stability and in sperm morphology. In contrast, the data indicated that sperm count, to a large extent, is determined by factors operating in the prenatal environment.

Although there are some examples of environmental disasters leading to subsequent impairment of semen quality among the exposed subjects [41], there are no substantial data demonstrating a link between the exposure at levels in the general population and sperm parameters, one of the exceptions being the pre- and postnatal effects of cigarette smoking [42-44].

Androgens are known to play an important role in normal sperm production [45]. The androgen 
receptor (AR) function is modified by two polymorphic sequences, a polyglutamine-encoding trinucleotide repeat of $\mathrm{C}$, A and $\mathrm{G}$ bases (CAG repeats) and another repeat of GG and any of the four nucleotides, encoding for polyglycine (GGN repeat). Some studies have indicated an inverse correlation between the number of CAG repeats and receptor function [46], although others found this association to be non-linear [47].

The CAG number was claimed to be inversely correlated with sperm number [48], and a recent study found an association between $A R$ CAG polymorphism and sperm motility [49], wherein long repeats were associated with higher sperm motility. In the same study, men with certain alleles of the sex hormone-binding globulin gene had a higher sperm concentration. This indicates that not only genetic disease states but also normal variants in genes can affect male semen quality.

Recent data also indicate that polymorphisms in the $A R$ not only have a direct impact on spermatogenesis but also modulate the effects of ED (Table 1).

In an EU-supported study (www.inuendo.dk) on the impact of POPs on human reproductive function, an interaction between the length of the $A R$ CAG repeats and blood levels of a metabolite of the banned pesticide dichlorodiphenyltrichloroethane's metabolite, $p, p^{\prime}$ 1,1-dichloro-2,2-bis ( $p$-chlorophenyl) ethylene (DDE), in relation to the degree of DNA fragmentation in human sperm was found among Europeans, but not in Inuit men [50]. In the Europeans with a CAG stretch shorter than the median length, the DNA fragmentation index (DFI), as a measure of DNA damage, was $40 \%$ higher in highly exposed men than in those with low $p, p^{\prime}$-DDE exposure. This effect was absent among those with longer CAG repeats. In the same study, an interactive effect was also observed between the PCB marker 2,2',4,4',5,5'-hexachlorobiphenyl (CB-153) and polymorphisms in the $A R$ gene in relation to sperm counts. In subjects with CAG numbers below 20 and highly exposed to the compound, total sperm number was $40 \%$ lower as compared with men with CB-153 levels above the median. Seemingly, men with short $\mathrm{CAG}$ repeats were more sensitive to the deleterious effects of PCB and $p, p^{\prime}$-DDE.

In Chinese workers, the effects of organophosphate pesticides on semen quality have been studied in relation to polymorphisms in the paraoxonase gene, which is involved in the metabolism of these pesticides [51]. In the Chinese study, organophosphate pesticide exposure was associated with decreased sperm count and sperm concentration, but unexpectedly, exposed men with a variant of the paraoxonase gene encoding for a less efficient detoxifying enzyme had higher sperm counts and better morphology compared with exposed men with the more effective variant. Caution is warranted because the sample size was very small and also in an earlier study a negative impact on semen volume and sperm count per se was reported [52], although the evidence is not entirely consistent [53].

An additional example of gene-environment interaction is the finding of an association between air pollution and the sperm DFI, in which a variant of the detoxifying enzyme, glutathione- $S$-transferase M1, was shown to increase susceptibility to the pollution, so that individuals who were carrying this genotype were less able to detoxify the reactive metabolites of carcinogenic polycyclic aromatic hydrocarbons [54].

The C677T polymorphism in the gene encoding for methylenetetrahydrofolate reductase, which is one of the key enzymes in the folate metabolism, was studied in 113 fertile and 77 sub-fertile males, and it was shown that the positive effect of folic acid and zinc sulphate supplementation on sperm concentration was seen only in subjects without the T-variant (CC homozygotes) [55]. However, in this study, the polymorphism itself was not a risk factor for male sub-fertility.

\subsection{Hypospadias and cryptorchidism}

A slight decrease in AR function due to an expanded GGN repeat sequence [56] has been suggested to predispose to development of penile hypospadias (but not glandular or penoscrotal) and to cryptorchidism, probably in combination with a hypoandrogenic milieu in the foetus [57]. Furthermore, the high proportion of the population in Greenland carrying the GGN length of 23 (85\%) compared with Caucasians (54\%) has been suggested to at least partly explain why, despite an extremely high exposure to POP among the Inuit population, the incidence of hypospadias in Greenland is 10 times lower than in Sweden [58].

A maternal genetic factor related to detoxification of environmental chemicals and estrogen metabolism (polymorphism in CYP1A1 gene) has also been associated with the risk of hypospadias in a Japanese case-control study including 31 cases and 64 controls [59].

\section{The impact of environment and lifestyle on the genome of spermatozoa}

An alternative interpretation of the term 'gene- 
environment interaction' in relation to male reproductive function is a scenario in which environmental or lifestyle-related exposure introduces damage to the sperm chromatin, there being a potential risk of such genomic changes being transmitted to the generations to come.

Paternal smoking has been reported to introduce sperm DNA damage [60] and an increased risk of childhood cancer in the offspring in some studies [6163]. However, others could not find these associations $[64,65]$.

Paternal occupation has also been linked to certain birth defects or diseases in the offspring, possibly due to genetic or epigenetic mechanisms [66]. Epigenetic abnormalities have been associated with imprinting diseases, for which a paternal role has been reported [67], and suggested to be increased in babies following conception by assisted reproduction.

Foetal exposure to the pesticide vinclozolin was also suggested to introduce epigenetic changes, which would be passed to and would induce sub-fertility in, at least, three subsequent generations in rats [68]. These results have, however, not been replicated in two later studies $[69,70]$.

Studies on humans have also shown that environmental exposure may have an impact on sperm DNA. Serum levels of CB-153, a marker of PCB exposure, were shown to be positively associated with the DFI measured using sperm chromatin structure assay. Interestingly, this effect was seen only in Caucasian men but not in Inuit $[71,72]$. It remains to be seen whether the relatively lower sensitivity of Inuit in relation to PCB-related sperm DNA damage is genetically dependent or relates to other types of concomitant exposure, as for example, nutritional factors [50].

The level of exposure to other EDs, namely two different phthalate esters, monoethyl phthalate (MEP) and mono-(2-ethylhexyl) phthalate (MEHP), was also found to be associated with the degree of sperm DNA damage [73].

Lifestyle changes in the society have also contributed to an increase in paternal age, which per se is associated with an increase in sperm double-stranded DNA breaks [74]. These are in turn associated with genetic disorders, such as achondroplasia and Apert's syndrome, and also diseases of complex aetiology, such as schizophrenia [75].

Interestingly, a study on parental occupation and risk of TC showed increased risks associated with fathers who were wood processors $(\mathrm{OR}=10.46)$, metal workers $(\mathrm{OR}=3.28)$, employees of food products
$(\mathrm{OR}=2.79)$, metal products $(\mathrm{OR}=5.77)$, and food and beverage services $(\mathrm{OR}=4.36)$, but there was little evidence of risk associated with maternal employment [76]. In another study, no significant associations with occupation were found for all histological types of TC combined, whereas, for cases with seminomas, excess risks were seen for those with mothers in healthrelated occupations $(\mathrm{OR}=4.6)$ and fathers working in automobile service stations $(\mathrm{OR}=4.0)$, manufacturing industries $(\mathrm{OR}=2.2)$, and aircraft production and maintenance $(\mathrm{OR}=5.3)$ [77].

Furthermore, male welding of stainless steel has been associated with an increased risk of spontaneous abortion in spouses [78].

A Dutch study on the parental risk factors for cryptorchidism and hypospadias found that paternal pesticide exposure was associated with cryptorchidism and that paternal smoking was associated with hypospadias [79].

It could be speculated that the above-mentioned effects of paternal exposure might be mediated through exposure-related alterations in the sperm genome.

\subsection{Risks of transmitting genetic damage to children by assisted reproduction techniques}

Sperm DNA damage seems to have a significant impact on the fertility in vivo, without affecting the chance of pregnancy following use of in vitro methods [80]. Thus, it can be argued that assisted reproduction techniques may by-pass the natural selection, especially when intracytoplasmatic sperm injection (ICSI) is used [81]. In fact, more birth defects, especially urogenital malformations in boys, have been reported in children born after ICSI compared with natural conception [82]. It is, however, not known whether this increase is due to chromatin damage, related to the infertility problem, that subsequently is transferred to the offspring through ICSI or owing to some other cause.

Perhaps not surprisingly, paternal $\mathrm{Y}$ chromosome polymorphisms or rearrangements in the azoospermia factor region, leading to a compromised fertility, have been shown to be inherited by the sons through assisted reproduction [83].

\section{Concluding remarks}

Information regarding how genetic predisposition may modify the adverse environmental effects on male reproductive health is still very scarce. Few examples 
indicate that such mechanisms are plausible. The study of gene-environment interaction can help to dissect disease mechanisms in humans as well as determine specific exposures related to the risk of disease [14, 84]. It provides both a useful means to improve our understanding of normal physiology [85] and pathology at the molecular level, as well as allows specific targeting of prevention and therapies to high-risk subjects [86]. A multi-disciplinary collaboration is necessary in order to carry out studies addressing this issue.

\section{Acknowledgment}

The studies of our research groups were supported by grants from the Swedish Research Council (grants K2009-54X-21116-01-3; 521-2004-6072), the European Commission to the 5th Framework Programme Quality of Life and Management of living resources, Key action four on environment and health, (Contract No. QLK4CT-2001-00202), INTAS (Contract No. 2001 2205), the Swedish Research Council for Environment, Agricultural sciences and Spatial Planning,the Swedish Cancer Society (grant 2009/817), Cancer Research Fund of Malmö University Hospital, the Gunnar Nilsson Cancer Foundation.

\section{References}

1 Giwercman A, Skakkebaek NE. The human testis-an organ at risk? Int J Androl 1992; 15: 373-5.

2 Olesen IA, Sonne SB, Hoei-Hansen CE, Rajpert-DeMeyts E, Skakkebaek NE. Environment, testicular dysgenesis and carcinoma in situ testis. Best Pract Res Clin Endocrinol Metab 2007; 21: 462-78.

3 Jouannet P, Wang C, Eustache F, Kold-Jensen T, Auger J. Semen quality and male reproductive health: the controversy about human sperm concentration decline. APMIS 2001; 109: 333-44.

4 Fisch H. Declining worldwide sperm counts: disproving a myth. Urol Clin North Am 2008; 35: 137-46, vii.

5 Richiardi L, Bellocco R, Adami HO, Torrang A, Barlow L, et al. Testicular cancer incidence in eight northern European countries: secular and recent trends. Cancer Epidemiol Biomarkers Prev 2004; 13: 2157-66.

6 Paulozzi LJ. International trends in rates of hypospadias and cryptorchidism. Environ Health Perspect 1999; 107: 297-302.

7 Boisen KA, Kaleva M, Main KM, Virtanen HE, Haavisto $\mathrm{AM}$, et al. Difference in prevalence of congenital cryptorchidism in infants between two Nordic countries. Lancet 2004; 363: 1264-9.

8 Carlsen E, Giwercman A, Keiding N, Skakkebaek NE. Evidence for decreasing quality of semen during past 50 years.
BMJ 1992; 305: 609-13.

9 Swan SH, Elkin EP, Fenster L. The question of declining sperm density revisited: an analysis of 101 studies published 1934-1996. Environ Health Perspect 2000; 108: 961-6.

10 Holmes L Jr., Escalante C, Garrison O, Foldi BX, Ogungbade GO, et al. Testicular cancer incidence trends in the USA (1975-2004): plateau or shifting racial paradigm? Public Health 2008; 122: 862-72.

11 Susser M. Does risk factor epidemiology put epidemiology at risk? Peering into the future. J Epidemiol Community Health 1998; 52: 608-11.

12 Taubes G. Epidemiology faces its limits. Science 1995; 269: 164-9.

13 Lewis SJ, Smith GD. Alcohol, ALDH2, and esophageal cancer: a meta-analysis which illustrates the potentials and limitations of a Mendelian randomization approach. Cancer Epidemiol Biomarkers Prev 2005; 14: 1967-71.

14 Hunter DJ. Gene-environment interactions in human diseases. Nat Rev Genet 2005; 6: 287-98.

15 Taioli E. Gene-environment interaction in tobacco-related cancers. Carcinogenesis 2008; 29: 1467-74.

16 Chen D, Tian T, Wang H, Liu H, Hu Z, et al. Association of human aryl hydrocarbon receptor gene polymorphisms with risk of lung cancer among cigarette smokers in a Chinese population. Pharmacogenet Genomics 2009; 19: 25-34.

17 Andreasen $\mathrm{CH}$, Andersen G. Gene-environment interactions and obesity-further aspects of genomewide association studies. Nutrition 2009; 25: 998-1003.

18 Ordovas JM, Shen J. Gene-environment interactions and susceptibility to metabolic syndrome and other chronic diseases. J Periodontol 2008; 79: 1508-13.

19 Andreassi MG. Metabolic syndrome, diabetes and atherosclerosis: influence of gene-environment interaction. Mutat Res 2009; 667: 35-43.

20 Skakkebaek NE, Rajpert-De Meyts E, Main KM. Testicular dysgenesis syndrome: an increasingly common developmental disorder with environmental aspects. Hum Reprod 2001; 16: 972-8.

21 Simanainen U, Adamsson A, Tuomisto JT, Miettinen HM, Toppari J, et al. Adult 2,3,7,8-tetrachlorodibenzo-p-dioxin (TCDD) exposure and effects on male reproductive organs in three differentially TCDD-susceptible rat lines. Toxicol Sci 2004; 81: 401-7.

22 Simanainen U, Haavisto T, Tuomisto JT, Paranko J, Toppari $\mathrm{J}$, et al. Pattern of male reproductive system effects after in utero and lactational 2,3,7,8-tetrachlorodibenzo-p-dioxin (TCDD) exposure in three differentially TCDD-sensitive rat lines. Toxicol Sci 2004; 80: 101-8.

23 Johnson KJ, McCahan SM, Si X, Campion L, Herrmann R, et al. The orl rat with inherited cryptorchidism has increased susceptibility to the testicular effects of in utero dibutyl phthalate exposure. Toxicol Sci 2008; 105: 360-7.

24 Myrup C, Westergaard T, Schnack T, Oudin A, Ritz C, et al. Testicular cancer risk in first- and second-generation immigrants to Denmark. J Natl Cancer Inst 2008; 100: 41-7.

25 Hemminki K, Li X. Cancer risks in Nordic immigrants and their offspring in Sweden. Eur J Cancer 2002; 38: 2428-34.

26 Hardell L, van Bavel B, Lindstrom G, Carlberg M, Dreifaldt 
$\mathrm{AC}$, et al. Increased concentrations of polychlorinated biphenyls, hexachlorobenzene, and chlordanes in mothers of men with testicular cancer. Environ Health Perspect 2003; 111: $930-4$

27 Hardell L, Van Bavel B, Lindstrom G, Carlberg M, Eriksson $\mathrm{M}$, et al. Concentrations of polychlorinated biphenyls in blood and the risk for testicular cancer. Int J Androl 2004; 27: 282-90.

28 Dong C, Hemminki K. Modification of cancer risks in offspring by sibling and parental cancers from 2,112,616 nuclear families. Int J Cancer 2001; 92: 144-50.

29 Swerdlow AJ, De Stavola BL, Swanwick MA, Maconochie NE. Risks of breast and testicular cancers in young adult twins in England and Wales: evidence on prenatal and genetic aetiology. Lancet 1997; 350: 1723-8.

30 Hannema SE, Scott IS, Rajpert-De Meyts E, Skakkebaek NE, Coleman N, et al. Testicular development in the complete androgen insensitivity syndrome. J Pathol 2006; 208: 518-27.

31 Rapley EA, Turnbull C, Al Olama AA, Dermitzakis ET, Linger R, et al. A genome-wide association study of testicular germ cell tumor. Nat Genet 2009; 41: 807-10.

32 Chia VM, Li Y, Quraishi SM, Graubard BI, Figueroa JD, et al. Effect modification of endocrine disruptors and testicular germ cell tumour risk by hormone-metabolizing genes. Int J Androl 2009 July 13, [Epub ahead of print].

33 McGlynn KA, Quraishi SM, Graubard BI, Weber JP, Rubertone $\mathrm{MV}$, et al. Persistent organochlorine pesticides and risk of testicular germ cell tumors. J Natl Cancer Inst 2008; 100: 663-71.

34 Figueroa JD, Sakoda LC, Graubard BI, Chanock S, Rubertone $\mathrm{MV}$, et al. Genetic variation in hormone metabolizing genes and risk of testicular germ cell tumors. Cancer Causes Control 2008; 19: 917-29.

35 McGlynn KA, Quraishi SM, Graubard BI, Weber JP, Rubertone MV, et al. Polychlorinated biphenyls and risk of testicular germ cell tumors. Cancer Res 2009; 69: 1901-9.

36 Dieckmann KP, Skakkebaek NE. Carcinoma in situ of the testis: review of biological and clinical features. Int $\mathrm{J}$ Cancer 1999; 83: 815-22.

37 Longnecker MP, Rogan WJ, Lucier G. The human health effects of DDT (dichlorodiphenyltrichloroethane) and PCBS (polychlorinated biphenyls) and an overview of organochlorines in public health. Annu Rev Public Health 1997; 18: 211-44.

38 Hull MG, Glazener CM, Kelly NJ, Conway DI, Foster PA, et al. Population study of causes, treatment, and outcome of infertility. Br Med J (Clin Res Ed) 1985; 291: 1693-7.

39 Hargreave TB. Genetics and male infertility. Curr Opin Obstet Gynecol 2000; 12: 207-19.

40 Storgaard L, Bonde JP, Ernst E, Andersen CY, Spano M, et al. Genetic and environmental correlates of semen quality: a twin study. Epidemiology 2006; 17: 674-81.

41 Guo YL, Hsu PC, Hsu CC, Lambert GH. Semen quality after prenatal exposure to polychlorinated biphenyls and dibenzofurans. Lancet 2000; 356: 1240-1.

42 Smoking and infertility. Fertil Steril 2006; 86: S172-7.

43 Richthoff J, Elzanaty S, Rylander L, Hagmar L, Giwercman
A. Association between tobacco exposure and reproductive parameters in adolescent males. Int J Androl 2008; 31: 31-9.

44 Storgaard L, Bonde JP, Ernst E, Spano M, Andersen CY, et al. Does smoking during pregnancy affect sons' sperm counts? Epidemiology 2003; 14: 278-86.

45 De Gendt K, Swinnen JV, Saunders PT, Schoonjans L, Dewerchin M, et al. A Sertoli cell-selective knockout of the androgen receptor causes spermatogenic arrest in meiosis. Proc Natl Acad Sci USA 2004; 101: 1327-32.

46 Chamberlain NL, Driver ED, Miesfeld RL. The length and location of CAG trinucleotide repeats in the androgen receptor $\mathrm{N}$-terminal domain affect transactivation function. Nucleic Acids Res 1994; 22: 3181-6.

47 Nenonen H, Bjork C, Skjaerpe PA, Giwercman A, Rylander $\mathrm{L}$, et al. CAG repeat number is not inversely associated with androgen receptor activity in vitro. Mol Hum Reprod 2009.

48 von Eckardstein S, Syska A, Gromoll J, Kamischke A, Simoni $\mathrm{M}$, et al. Inverse correlation between sperm concentration and number of androgen receptor CAG repeats in normal men. J Clin Endocrinol Metab 2001; 86: 2585-90.

49 Lazaros L, Xita N, Kaponis A, Zikopoulos K, Sofikitis N, et al. Evidence for association of sex hormone-binding globulin and androgen receptor genes with semen quality. Andrologia 2008; 40: 186-91.

50 Giwercman A, Rylander L, Rignell-Hydbom A, Jonsson BA, Pedersen HS, et al. Androgen receptor gene CAG repeat length as a modifier of the association between persistent organohalogen pollutant exposure markers and semen characteristics. Pharmacogenet Genomics 2007; 17: 391-401.

51 Padungtod C, Niu T, Wang Z, Savitz DA, Christiani DC, et al. Paraoxonase polymorphism and its effect on male reproductive outcomes among Chinese pesticide factory workers. Am J Ind Med 1999; 36: 379-87.

52 Recio-Vega R, Ocampo-Gomez G, Borja-Aburto VH, Moran-Martinez J, Cebrian-Garcia ME. Organophosphorus pesticide exposure decreases sperm quality: association between sperm parameters and urinary pesticide levels. J Appl Toxicol 2008; 28: 674-80.

53 Perry MJ. Effects of environmental and occupational pesticide exposure on human sperm: a systematic review. Hum Reprod Update 2008; 14: 233-42.

54 Rubes J, Selevan SG, Sram RJ, Evenson DP, Perreault SD. GSTM1 genotype influences the susceptibility of men to sperm DNA damage associated with exposure to air pollution. Mutat Res 2007; 625: 20-8.

55 Ebisch IM, van Heerde WL, Thomas CM, van der Put $\mathrm{N}$, Wong WY, et al. C677T methylenetetrahydrofolate reductase polymorphism interferes with the effects of folic acid and zinc sulfate on sperm concentration. Fertil Steril 2003; 80: 1190-4.

56 Lundin KB, Giwercman A, Dizeyi N, Giwercman YL. Functional in vitro characterisation of the androgen receptor GGN polymorphism. Mol Cell Endocrinol 2007; 264: 184-7.

57 Aschim EL, Nordenskjold A, Giwercman A, Lundin KB, Ruhayel Y, et al. Linkage between cryptorchidism, hypospadias, and GGN repeat length in the androgen receptor gene. J Clin Endocrinol Metab 2004; 89: 5105-9. 
58 Giwercman YL, Kleist KE, Giwercman A, Giwercman C, Toft $\mathrm{G}$, et al. Remarkably low incidence of hypospadias in Greenland despite high exposure to endocrine disrupters; possible protective effect of androgen receptor genotype. Pharmacogenet Genomics 2006; 16: 375-7.

59 Kurahashi N, Sata F, Kasai S, Shibata T, Moriya K, et al. Maternal genetic polymorphisms in CYP1A1, GSTM1 and GSTT1 and the risk of hypospadias. Mol Hum Reprod 2005; 11: 93-8.

60 Elshal MF, E1-Sayed IH, Elsaied MA, El-Masry SA, Kumosani TA. Sperm head defects and disturbances in spermatozoal chromatin and DNA integrities in idiopathic infertile subjects: association with cigarette smoking. Clin Biochem 2009; 42: 589-94.

61 Sorahan T, Lancashire RJ, Hulten MA, Peck I, Stewart AM. Childhood cancer and parental use of tobacco: deaths from 1953 to 1955 . Br J Cancer 1997; 75: 134-8.

62 Sorahan T, McKinney PA, Mann JR, Lancashire RJ, Stiller $\mathrm{CA}$, et al. Childhood cancer and parental use of tobacco: findings from the inter-regional epidemiological study of childhood cancer (IRESCC). Br J Cancer 2001; 84: 141-6.

63 Ji BT, Shu XO, Linet MS, Zheng W, Wacholder S, et al. Paternal cigarette smoking and the risk of childhood cancer among offspring of nonsmoking mothers. J Natl Cancer Inst 1997; 89: 238-44.

64 Viloria T, Meseguer M, Martinez-Conejero JA, O'Connor $\mathrm{JE}$, Remohi $\mathrm{J}$, et al. Cigarette smoking affects specific sperm oxidative defense but does not cause oxidative DNA damage in infertile men. Fertil Steril 2009 April 24, [Epub ahead of print].

65 Schuz J, Kaatsch P, Kaletsch U, Meinert R, Michaelis J. Association of childhood cancer with factors related to pregnancy and birth. Int J Epidemiol 1999; 28: 631-9.

66 Whalley LJ, Thomas BM, McGonigal G, McQuade CA, Swingler R, et al. Epidemiology of presenile Alzheimer's disease in Scotland (1974-88) I. non-random geographical variation. Br J Psychiatry 1995; 167: 728-31.

67 Marques CJ, Carvalho F, Sousa M, Barros A. Genomic imprinting in disruptive spermatogenesis. Lancet 2004; 363 : 1700-2.

68 Anway MD, Cupp AS, Uzumcu M, Skinner MK. Epigenetic transgenerational actions of endocrine disruptors and male fertility. Science 2005; 308: 1466-9.

69 Inawaka K, Kawabe M, Takahashi S, Doi Y, Tomigahara $\mathrm{Y}$, et al. Maternal exposure to anti-androgenic compounds, vinclozolin, flutamide and procymidone, has no effects on spermatogenesis and DNA methylation in male rats of subsequent generations. Toxicol Appl Pharmacol 2009; 237: $178-87$.

70 Schneider S, Kaufmann W, Buesen R, van Ravenzwaay B. Vinclozolin-the lack of a transgenerational effect after oral maternal exposure during organogenesis. Reprod Toxicol 2008; 25: 352-60.

71 Rignell-Hydbom A, Rylander L, Giwercman A, Jonsson BA, Lindh $\mathrm{C}$, et al. Exposure to PCBs and $p, p^{\prime}$-DDE and human sperm chromatin integrity. Environ Health Perspect 2005;
113: 175-9.

72 Bonde JP, Toft G, Rylander L, Rignell-Hydbom A, Giwercman $\mathrm{A}$, et al. Fertility and markers of male reproductive function in Inuit and European populations spanning large contrasts in blood levels of persistent organochlorines. Environ Health Perspect 2008; 116: 269-77.

73 Hauser R, Meeker JD, Singh NP, Silva MJ, Ryan L, et al. DNA damage in human sperm is related to urinary levels of phthalate monoester and oxidative metabolites. Hum Reprod 2007; 22: 688-95.

74 Singh NP, Muller CH, Berger RE. Effects of age on DNA double-strand breaks and apoptosis in human sperm. Fertil Steril 2003; 80: 1420-30.

75 Kuhnert B, Nieschlag E. Reproductive functions of the ageing male. Hum Reprod Update 2004; 10: 327-39.

76 Knight JA, Marrett LD. Parental occupational exposure and the risk of testicular cancer in Ontario. J Occup Environ Med 1997; 39: 333-8.

77 Kardaun JW, Hayes RB, Pottern LM, Brown LM, Hoover RN. Testicular cancer in young men and parental occupational exposure. Am J Ind Med 1991; 20: 219-27.

78 Hjollund NH, Bonde JP, Jensen TK, Henriksen TB, Andersson AM, et al. Male-mediated spontaneous abortion among spouses of stainless steel welders. Scand J Work Environ Health 2000; 26: 187-92.

79 Pierik FH, Burdorf A, Deddens JA, Juttmann RE, Weber RF. Maternal and paternal risk factors for cryptorchidism and hypospadias: a case-control study in newborn boys. Environ Health Perspect 2004; 112: 1570-6.

80 Bungum M, Humaidan P, Axmon A, Spano M, Bungum $\mathrm{L}$, et al. Sperm DNA integrity assessment in prediction of assisted reproduction technology outcome. Hum Reprod 2007; 22: 174-9.

81 Barroso G, Morshedi M, Oehninger S. Analysis of DNA fragmentation, plasma membrane translocation of phosphatidylserine and oxidative stress in human spermatozoa. Hum Reprod 2000; 15: 1338-44.

82 Bonduelle M, Wennerholm UB, Loft A, Tarlatzis BC, Peters $\mathrm{C}$, et al. A multi-centre cohort study of the physical health of 5-year-old children conceived after intracytoplasmic sperm injection, in vitro fertilization and natural conception. Hum Reprod 2005; 20: 413-9.

83 Mau Kai C, Juul A, McElreavey K, Ottesen AM, Garn ID, et al. Sons conceived by assisted reproduction techniques inherit deletions in the azoospermia factor (AZF) region of the Y chromosome and the DAZ gene copy number. Hum Reprod 2008; 23: 1669-78.

84 Kelada SN, Eaton DL, Wang SS, Rothman NR, Khoury MJ. The role of genetic polymorphisms in environmental health. Environ Health Perspect 2003; 111: 1055-64.

85 Giwercman A, Rylander L, Hagmar L, Giwercman YL. Ethnic differences in occurrence of TDS-genetics and/or environment? Int J Androl 2006; 29: 291-7; discussion 304-6.

86 Shen J. Evaluation of environmental and personal susceptibility characteristics that modify genetic risks. Methods Mol Biol 2009; 471: 163-77. 